Research article

Open Access

\title{
Detection and characterization of circulating tumor cells in blood of primary breast cancer patients by RT-PCR and comparison to status of bone marrow disseminated cells
}

\author{
Tanja Fehm 1 , Oliver Hoffmann², Bahriye Aktas ${ }^{2}$, Sven Becker ${ }^{1}$, Erich F Solomayer ${ }^{1}$, \\ Diethelm Wallwiener ${ }^{1}$, Rainer Kimmig ${ }^{2}$ and Sabine Kasimir-Bauer ${ }^{2}$
}

\author{
1Department of Gynecology and Obstetrics, Calwer Straße 7, University Hospital of Tuebingen, D-72076 Tuebingen, Germany \\ 2Department of Gynecology and Obstetrics, Hufelandstraße 55, University Hospital of Essen, D-45122 Essen, Germany \\ Corresponding author: Tanja Fehm, tanja.fehm@med.uni-tuebingen.de
}

Received: 9 Apr 2009 Revisions requested: 18 May 2009 Revisions received: 2 Aug 2009 Accepted: 10 Aug 2009 Published: 10 Aug 2009

Breast Cancer Research 2009, 11:R59 (doi:10.1186/bcr2349)

This article is online at: http://breast-cancer-research.com/content/11/4/R59

(c) 2009 Fehm et al.; licensee BioMed Central Ltd.

This is an open access article distributed under the terms of the Creative Commons Attribution License (http://creativecommons.org/licenses/by/2.0), which permits unrestricted use, distribution, and reproduction in any medium, provided the original work is properly cited.

\begin{abstract}
Introduction The role of circulating tumor cells (CTCs) in blood of primary breast cancer patients is still under investigation. We evaluated the incidence of CTCs in blood, we evaluated the correlation between CTCs and disseminated tumor cells (DTCs) in the bone marrow (BM), and we characterized CTCs for the expression of HER2, the estrogen receptor (ER) and the progesterone receptor (PR).

Methods Blood of 431 patients with primary breast cancer were analyzed for EpCAM, MUC1 and HER2 transcripts with the AdnaTest BreastCancer ${ }^{\mathrm{TM}}$ (AdnaGen AG, Germany). Expression of the ER and PR was assessed in an additional RTPCR. BM aspirates from 414 patients were analyzed for DTCs by immunocytochemistry using the pan-cytokeratin antibody A45-B/B3.
\end{abstract}

Results DTCs were found in $107 / 414$ patients (24\%), CTCs were detected in 58/431 (13\%) patients. DTCs were associated with PR status of the primary tumor $(P=0.04)$ and CTCs significantly correlated with nodal status $(P=0.04)$, ER $(P=0.05)$, and PR $(P=0.01)$. DTCs in the BM weakly correlated with CTCs $(P=0.05)$ in blood. Interestingly, the spread of CTCs was mostly found in triple-negative tumors $(P=$ 0.01 ) and CTCs in general were mostly found to be triplenegative regardless of the ER, PR and HER2 status of the primary tumor.

Conclusions (1) Due to the weak concordance between CTCs and DTCs the clinical relevance may be different. (2) The biology of the primary tumor seems to direct the spread of CTCs. (3) Since the expression profile between CTCs and the primary tumor differs, the consequence for the selection of adjuvant treatment has to be evaluated.

\section{Introduction}

Disseminated tumor cells (DTCs) in the bone marrow (BM) are a common phenomenon seen in breast cancer at primary diagnosis in up to $40 \%$ of patients [1-3]. Tumor cell detection in the $\mathrm{BM}$ is regarded increasingly as a clinically relevant prognostic factor for breast cancer, and a pooled analysis of BM findings in more than 4,700 patients documented that their presence is associated with a poor prognosis [4]. In addition, it has been demonstrated that tumor cells frequently survive chemotherapy [5] and the persistence of these cells in BM after conventional adjuvant chemotherapy is associated with poor prognosis [6-8]. The consequences for a possible secondary adjuvant therapy are under discussion. Since BM aspiration is less accepted by patients compared with blood drawing, it would be highly desirable to replace BM aspiration by blood analysis.

For the detection of circulating tumor cells (CTCs) in blood, both antibody-based assays using antibodies against epithelial specific markers (for example, cytokeratins (CKs)) and molecular assays (for example, based on amplification of

BM: bone marrow; bp: base pairs; CK: cytokeratin; CTC: circulating tumor cell; DTC: disseminated tumor cell; EpCAM: epithelial cell adhesion molecule; ER: estrogen receptor; HER2: human epidermal growth factor receptor 2; mAb: monoclonal antibody; PBS: phosphate-buffered saline; PCR: polymerase chain reaction; PR: progesterone receptor; RT: reverse transcriptase. 
epithelial-specific mRNA transcripts) have been established [9-20].

The most currently used approach, particularly in clinical trials, is the CellSearch ${ }^{\mathrm{TM}}$ System (Veridex, Warren, NJ, USA), which is as a semi-automated device based on immunofluorescence and flow cytometry. CTCs are isolated by immunomagnetic beads coated with antibodies against the epithelial cell adhesion molecule (EpCAM) and are identified by CK positivity, positive nuclear staining and CD45 negativity $[9,10,18]$.

Another commercially available CTC detection system is the AdnaTest BreastCancer ${ }^{\mathrm{TM}}$ (AdnaGen AG, Langenhagen, Germany). First, CTCs are isolated by immunomagnetic beads labeled with antibodies against MUC1 and EpCAM. After isolation of the mRNA, transcripts of epithelial-specific markers (GA 73.3, EpCAM and human epidermal growth factor receptor 2 (HER2)) are amplified by a multiplex PCR [21-23].

Based on current data, the concordance rate of the CellSearch $^{\mathrm{TM}}$ assay and the AdnaTest BreastCancer ${ }^{\mathrm{TM}}$ ranges between $68 \%$ and $88 \%$ [24,25]. A prospective multicenter trial in metastatic breast cancer using both methods - the CellSearch $^{\mathrm{TM}}$ assay and the AdnaTest BreastCancer ${ }^{\mathrm{TM}}$ - to reevaluate the HER2 status by circulating CTC has recently completed its recruitment, but the data on concordance have not yet been published [26].

The clinical significance of CTCs in metastatic breast cancer has been clearly demonstrated [9,10]. In contrast, the predictive and prognostic value of CTCs in primary breast cancer is still under investigation [11-17]. Single-center studies have indicated that the presence of CTCs at the time of first diagnosis is an independent prognostic factor for overall and disease-free survival $[11-13,27,28]$. In addition, patients with CTC persistence after completion of systemic cytotoxic therapy are more likely to develop relapse compared with those who were CTC-negative [29,30]. Targeting persistent CTCs is therefore an important issue to improve prognosis in primary breast cancer patients.

In this context, the need to determine the expression of therapeutic relevant markers in minimal residual disease is becoming increasingly important to optimize adjuvant treatment. Adjuvant therapy targets minimal residual disease, which is reflected by CTCs and DTCs. It has already been shown that the expression of therapeutic relevant markers including estrogen receptor (ER) and HER2 may differ from that of the primary tumor $[31,32]$. These observed discrepancies may be the cause of tumor cell persistence and therapeutic failure in the adjuvant setting.

In the present study we have used a RT-PCR-based approach to examine the presence of CTCs in peripheral blood of patients with primary breast cancer, to assess the correlation between CTCs in blood and DTCs in BM, and to compare the expression profile of therapeutic relevant markers (HER2, ER, progesterone receptor (PR)) between CTCs and the primary tumor.

\section{Materials and methods Patients' characteristics}

The study was conducted at the Department of Obstetrics and Gynecology in Essen and in the Department of Obstetrics and Gynecology in Tübingen. In total, 431 primary breast cancer patients (pT1 to pT4, pN0 to PN2, Mo) have been studied. Patients' characteristics at the time of diagnosis are presented in Table 1.

\section{Collection and analysis of bone marrow}

Between 10 and $20 \mathrm{ml} \mathrm{BM}$ were aspirated from the anterior iliac crests of 414 out of 431 primary breast cancer patients at the time of surgery and were processed within 24 hours. All specimens were obtained after written informed consent and were collected using protocols approved by the institutional review board (Protocol 114/2006A and Protocol 05/2856). Tumor cell isolation and detection was performed based on the recommendations for standardized tumor cell detection recently published by the German Consensus Group of Senology [33].

BM cells were isolated from heparinized BM $(5,000 \mathrm{U} / \mathrm{ml} \mathrm{BM})$ by Ficoll-Hypaque density gradient centrifugation (density $1.077 \mathrm{~g} / \mathrm{mol}$; Pharmacia, Freiburg, Germany) at $400 \times \mathrm{g}$ for 30 minutes. Interface cells were washed $(400 \times g$ for $15 \mathrm{~min})$ and resuspended in PBS. Then $1 \times 10^{6}$ mononuclear cells per area of $240 \mathrm{~mm}^{2}$ from each aspiration side were directly spun onto glass slides $(400 \times g$ for $5 \mathrm{~min}$ ) coated with poly-l-lysine (Sigma, Deisenhofen, Germany) using a Hettich cytocentrifuge (Tuttlingen, Germany) for the detection of CK-positive cells. The slides were air-dried overnight at room temperature.

\section{Immunocytochemistry}

Staining for CK-positive cells was performed using the murine mAb A45-B/B3 (Micromet, Munich, Germany), directed against a common epitope of $\mathrm{CK}$ polypeptides including the CK heterodimers $8 / 18$ and $8 / 19$ [13,27,28,32]. The protocol has been described in detail elsewhere [34]. Briefly, the method includes permeabilization of the cells with a detergent (5 $\mathrm{min})$, fixation with a formaldehyde-based solution (10 min), binding of the conjugate $\mathrm{mAb}$ A45-B/B3-alkaline phosphatase to cytoskeletal CKs (45 min), and formation of an insoluble red reaction product at the site of binding of the specific conjugate (15 min) using the DAKO-APAAP detection kit (DakoCytomation, Glostrup, Denmark) according to the manufacturer's instructions. Subsequently, the cells were mounted with Kaiser's glycerol/gelatine (Merck, Darmstadt, Germany) in Trisethylenediamine tetraacetic acid buffer (Sigma). A control antibody (conjugate of Fab fragment; Micromet) served as negative control. For each test a positive control slide with the 
Table 1

\begin{tabular}{|c|c|c|c|c|c|c|}
\hline & Total & CTC-positive & $P$ value & Total & DTC-positive & $P$ value \\
\hline Total & 431 & $58(13)$ & 414 & $107(24)$ & & \\
\hline \multicolumn{7}{|l|}{ Tumor size } \\
\hline pT1 & 285 & $34(12)$ & 0.47 & 274 & $66(24)$ & 0.07 \\
\hline pT2 to pT4* & 134 & $21(16)$ & 130 & $40(31)$ & & \\
\hline bilateral & 10 & $2(20)$ & 9 & $0(0)$ & & \\
\hline \multicolumn{7}{|l|}{ Nodal status } \\
\hline Node-negative & 286 & $32(11)$ & 0.04 & 273 & $71(26)$ & 0.92 \\
\hline Node-positive & 142 & $26(18)$ & 137 & $35(26)$ & & \\
\hline \multicolumn{7}{|l|}{ Histology } \\
\hline Ductal & 349 & $45(13)$ & 0.33 & 337 & $85(25)$ & 0.54 \\
\hline Lobular & 65 & $12(19)$ & 60 & $16(27)$ & & \\
\hline Others & 16 & $1(6)$ & 16 & $6(38)$ & & \\
\hline \multicolumn{7}{|l|}{ Grading } \\
\hline 1 & 58 & $6(10)$ & 0.11 & 57 & $14(25)$ & 0.76 \\
\hline$\|$ & 270 & $32(12)$ & 255 & $64(25)$ & & \\
\hline III & 102 & $20(20)$ & 101 & $29(29)$ & & \\
\hline \multicolumn{7}{|l|}{ ER status } \\
\hline Negative & 60 & $13(22)$ & 0.05 & 57 & $15(26)$ & 0.93 \\
\hline Positive & 371 & $45(12)$ & 357 & $92(26)$ & & \\
\hline \multicolumn{7}{|l|}{ PR status } \\
\hline Negative & 75 & $17(23)$ & 0.01 & 70 & $25(36)$ & 0.04 \\
\hline Positive & 356 & $41(12)$ & 344 & $82(24)$ & & \\
\hline \multicolumn{7}{|l|}{ HER2 } \\
\hline Negative & 380 & $49(13)$ & 0.35 & 365 & $89(24)$ & 0.06 \\
\hline Positive & 51 & $9(18)$ & 49 & $18(37)$ & & \\
\hline \multicolumn{7}{|l|}{ Bone marrow status } \\
\hline Positive & 106 & $20(19)$ & 0.05 & & & \\
\hline Negative & 299 & $34(11)$ & & & & \\
\hline \multicolumn{7}{|c|}{ Immunhistochemical subtype } \\
\hline (ER-, PR', HER2-) & 26 & $8(30)$ & 0.01 & 23 & $7(30)$ & 0.62 \\
\hline$\left(\mathrm{ER}^{-}, \mathrm{PR}-\mathrm{HER}^{+}{ }^{+}\right)$ & 11 & 0 & 11 & $4(36)$ & & \\
\hline$\left(\mathrm{ER}^{+}\right.$and/or $\left.\mathrm{PR}^{+}\right)$ & 394 & $50(13)$ & 380 & $96(25)$ & & \\
\hline
\end{tabular}

ER, estrogen receptor; HER2, human epidermal growth factor receptor 2; PR, progesterone receptor.

breast carcinoma cell line MCF-7 (ATCC, Rockville, MD, USA) was treated under the same conditions.

\section{Evaluation of CK-positive cells}

Microscopic evaluation of the slides was carried out using the ACIS system (Chromavision, San Juan Capistrano, CA, USA) at the Department of Gynecology and Obstetrics, Tübingen and using the ARIOL system (Applied Imaging, Newcastle upon Tyne, UK) at the Department of Gynecology and Obstetrics, Essen according to the ISHAGE evaluation criteria and the DTC consensus $[19,20]$. These automated scanning microscopes and image analysis systems consist of a slide 
loader, camera, computer and software for the detection and classification of cells of interest based on particular color, intensity, size, pattern, and shape. All slides were evaluated at both the Tübingen (TF) and Essen (SK-B) centers. In case nonconcordant results were obtained, slides were evaluated by a third investigator (EFS) to obtain consensus.

\section{Sampling of blood}

Two samples of $5 \mathrm{ml}$ ethylenediamine tetraacetic acid blood were collected for isolation of CTCs before the application of therapeutic substances with an S-Monovette ${ }^{\circledR}$ (Sarstedt AG \& Co, Nümbrecht, Germany) and were stored at $4^{\circ} \mathrm{C}$ until further examination. The samples were processed immediately or not later than 4 hours after blood withdrawal. An additional serum sample was collected to determine serum tumor markers.

\section{Tumor cell enrichment/selection}

Blood samples were taken from 431 patients and were analyzed for CTCs with the AdnaTest BreastCancer ${ }^{\mathrm{TM}}$ (AdnaGen $A G)$, which enables the immunomagnetic enrichment of tumor cells via epithelial and tumor-associated antigens. Establishment and validation of the AdnaTest BreastCancer ${ }^{\mathrm{TM}}$ assay has been described in detail elsewhere [21-23,35]. The lower detection limit of this assay is based on spiking experiments two cells per $5 \mathrm{ml}$ [35]. Examination of blood samples of healthy donors $(n=106)$ yielded a specificity of $95 \%$ [35].

In brief, blood samples were incubated with a ready-to-use antibody mixture (against GA 73.3 and MUC1) commercialized as AdnaTest BreastCancerSelect (AdnaGen AG, Langenhagen, Germany) according to the manufacturer's instructions. The labeled cells were extracted by a magnetic particle concentrator. Subsequently, mRNA isolation from lysed, enriched cells was performed according to the manufacturer's instructions with the Dynabeads mRNA DIRECT ${ }^{\mathrm{TM}}$ Micro Kit (Dynal Biotech $\mathrm{GmbH}$, Hamburg, Germany) that is included in the AdnaTest BreastCancerDetect (AdnaGen $A G)$. Reverse transcription resulted in cDNA, which was the template for tumor cell detection and characterization by multiplex RT-PCR. Sensiscript ${ }^{\circledR}$ Reverse Transcriptase (QIAGEN $\mathrm{GmbH}$, Hilden, Germany) was used for the reverse transcription because of its high sensitivity (recommended for $<50 \mathrm{ng}$ RNA) in combination with oligo(dT)-coupled Dynabeads of the mRNA DIRECT ${ }^{\mathrm{TM}}$ Micro Kit (Dynal Biotech $\mathrm{GmbH}$, Hamburg, Germany) according to the manufacturer's instructions [35].

\section{Tumor cell detection}

The Adnatest BreastCancerDetect was used for the detection of breast cancer-associated gene expression in immunomagnetically enriched tumor cells by reverse transcription and PCR. The analysis of tumor-associated mRNA isolated from CTCs was performed in a multiplex PCR for the three tumorassociated transcripts HER2, MUC1 and GA 733-2 followed by storage of the samples at $4^{\circ} \mathrm{C}$.
The primer sets for the ER and $P R$ receptor were provided by Adnagen AG. These reagents detected ER and PR on CTCs after the preparation of the cDNA and according to the manufacturer's instructions of the AdnaTest BreastCancerDetect. PCR was performed with the HotStarTaq Master Mix (QIAGEN GmbH). Actin was used as the internal PCR positive control. The thermal profile used for the nested RT-PCR was as follows. After a 15 -minute denaturation at $95^{\circ} \mathrm{C}, 37$ cycles of PCR were carried out by denaturation at $94^{\circ} \mathrm{C}$ for $30 \mathrm{sec}-$ onds, annealing/extension at $60^{\circ} \mathrm{C}$ for 30 seconds and elongation for 30 seconds at $72^{\circ} \mathrm{C}$. Termination of the reaction was subsequently carried out at $72^{\circ} \mathrm{C}$ for 5 minutes followed by storage of the samples at $4^{\circ} \mathrm{C}$.

The primers generate fragments of the following sizes: GA 733-2, 395 bp; MUC1, 293 bp; HER2, 270 bp; PR, 270 bp; ER, $305 \mathrm{bp}$; and actin, $114 \mathrm{bp}$. Visualization of the PCR fragments was carried out with a 2100 Bioanalyzer using the DNA 1000 LabChips (Agilent Technologies, Santa Clara, CA, USA) and the Expert Software Package (Agilent Technologies; version B.02.03.SI307).

Evaluation of data established for circulating tumor cells The test is considered positive if a PCR fragment of at least one tumor-associated transcript (MUC-1, GA 733-2 or HER2) is clearly detected. Using the software package for evaluation of the data on the Agilent 2100 Bioanalyzer, peaks with a concentration $>0.15 \mathrm{ng} / \mu \mathrm{l}$ are positive for the transcripts $\mathrm{GA}$ 733-2, MUC1 and HER2. Peaks with a concentration $>0.60$ $\mathrm{ng} / \mu \mathrm{l}$ are positive for the ER transcript. The PR expression is considered positive when the transcript is detected without applying any cutoff value.

\section{Immunohistochemical analysis of the primary tumor}

For each of the 431 patients, the tumor type, TNM staging and grading were assessed according to the World Health Organization Classification of tumors of the breast [36] and the sixth edition of the TNM Classification System [37].

The ER status and PR status were determined by immunohistochemistry. Sections of $5 \mu \mathrm{m}$ thickness were cut and mounted on SuperFrost ${ }^{\circledR}$ Plus slides (Menzel, Braunschweig, Germany). Following individually optimized heat-based antigen retrieval for each antibody, each glass slide was immunostained with commercially available antibodies. The following antibodies were used: anti-ER (clone SP1; DCS, Hamburg, Germany), dilution 1:300, antigen retrieval for 30 minutes in a $95^{\circ} \mathrm{C}$ waterbath, citrate buffer, $\mathrm{pH} 6.0$; and antiPR (clone 16; DCS), dilution 1:200, antigen retrieval for 30 minutes in a $95^{\circ} \mathrm{C}$ waterbath, citrate buffer, $\mathrm{pH} 6.0$.

Automated immunohistochemistry was performed using the Dako Autostainer Plus System (DakoCytomation, Carpinteria, CA, USA) with the anti-mouse IgG EnVision Plus detection kit (DakoCytomation) for secondary and tertiary immunoreac- 
tions. Reaction products were developed with diaminobenzidine, according to general protocols. Positive and negative control sections were included in each run, which showed appropriate results.

The DAKO score for the expression of HER2 was determined with the HercepTest, and fluorescence in situ hybridization analysis in cases of $2+$ staining as determined with the HercepTest was performed as described elsewhere [38].

\section{Statistical analysis}

The chi-squared test or Fisher's exact test was used to evaluate the relationship between DTCs and CTCs and clinicopathological factors. Statistical analysis was performed with SPSS software (version 11.5; SPSS Inc., Chicago, IL, USA). $P<0.05$ was considered statistically significant.

\section{Results}

\section{Patients' characteristics}

A total of 431 patients were included in the study: 285 out of $431(66 \%)$ patients had T1 tumors, and 286 out of $431(66 \%)$ patients were node-negative. The expression of therapeutic relevant markers in primary tumors was available from all 431 patients. ER and PR positivity was observed in 86\% (371/ $431)$ and $83 \%(356 / 431)$ of the tumors, respectively. HER2 was overexpressed in 12\% (51/431) of the cases. Classifying tumors into subtypes based on their ER, PR and HER2 expression, $91 \%$ of the tumors were ER-positive and/or PR-positive, 6\% were triple-negative (ER-negative/PR-negative/HER2negative) and 11 tumors only expressed HER2 (ER-negative/ PR-negative/HER2-positive). Clinical data are presented in detail in Table 1.

\section{Incidence of circulating tumor cells in blood}

A blood sample was regarded CTC-positive if at least one of the three markers GA 733-2, MUC1 or HER2 was expressed. The detection rate for CTCs was 13\% (58/431 patients) with the expression rates of $55 \%$ for EpCAM (32/58 patients), $53 \%$ for MUC1 (31/58 patients) and 38\% for HER2 (22/58 patients) (Table 2). The presence of CTCs significantly corre- lated with positive nodal status $(P=0.04)$, negative ER $(P=$ $0.05)$ and negative PR $(P=0.01)$, respectively. The highest CTC positivity rate was obtained in triple-negative patients followed by those with ER-positive and/or PR-positive tumors (30\% vs. $13 \%, P=0.01$ ). No CTCs could be detected in the HER2-positive subtype group (Table 1).

\section{Correlation of disseminated and circulating tumor cells with established prognostic markers}

The BM status of DTCs was available in 414 patients. DTCs were found in 107 out of 414 (24\%) patients. No correlation could be observed between positive BM status and the established prognostic markers except for the PR status of the primary tumor $(P=0.04$; Table 1$)$. The CTC status was weakly associated with the presence of DTCs in BM $(P=0.05$; Table 1). The positivity rate was $19 \%$ in patients with positive $B M$ status compared with $11 \%$ in those with negative BM status.

\section{Expression profiling of circulating tumor cells and corresponding tumors}

The expression profile of CTCs included ER, PR, and HER2. The expression rates were 38\% for HER2 (22/58 patients), $25 \%$ for ER (12/48 patients) and 4\% for PR (2/48 patients). In 10 patients, the ER and PR expression could not be determined in CTCs due to the small sample volume. Regarding the immunohistochemical subtype, 50\% of the CTCs (24/48 patients) were triple-negative and $21 \%$ (10/48 patients) were only HER2-positive. The remaining $29 \%$ of CTCs (14/48 patients) were ER-positive and/or PR-positive with positive or negative HER2 status. Comparing the expression profile between CTCs and the primary tumor, ER positivity of the primary tumor was demonstrated in 45 out of 58 (78\%) of these patients, PR positivity in 41 out of 58 (71\%) patients and HER2 positivity in 9 out of 58 (16\%) patients. The concordance rate between ER, PR and HER2 status of CTCs and the primary tumor was $29 \%, 25 \%$ and $53 \%$, respectively (Table 2). Interestingly, CTCs were triple-negative in $50 \%$ (24/48) of all cases whereas only $15 \%(7 / 48)$ of the primary tumors were negative for ER, PR and HER2 (see Figure 1).

Table 2

Expression profile of circulating tumor cells in breast cancer patients compared with the primary tumor

\begin{tabular}{|c|c|c|c|c|c|c|}
\hline & \multirow[b]{2}{*}{$n$} & \multicolumn{2}{|c|}{ Circulating tumor cells } & \multicolumn{2}{|c|}{ Primary tumor $(n=58)$} & \multirow[t]{2}{*}{ Concordance (\%) } \\
\hline & & $n$ & $\%$ & $n$ & $\%$ & \\
\hline ER-positive & 48 & 12 & 25 & 45 & 78 & 29 \\
\hline PR-positive & 48 & 2 & 2 & 41 & 71 & 25 \\
\hline HER2-positive & 58 & 22 & 38 & 9 & 16 & 53 \\
\hline Muc-1-positive & 58 & 31 & 53 & - & - & - \\
\hline GA 73.3-positive & 58 & 32 & 55 & - & - & - \\
\hline
\end{tabular}

ER, estrogen receptor; HER2, human epidermal growth factor receptor 2; PR, progesterone receptor. 
Figure 1

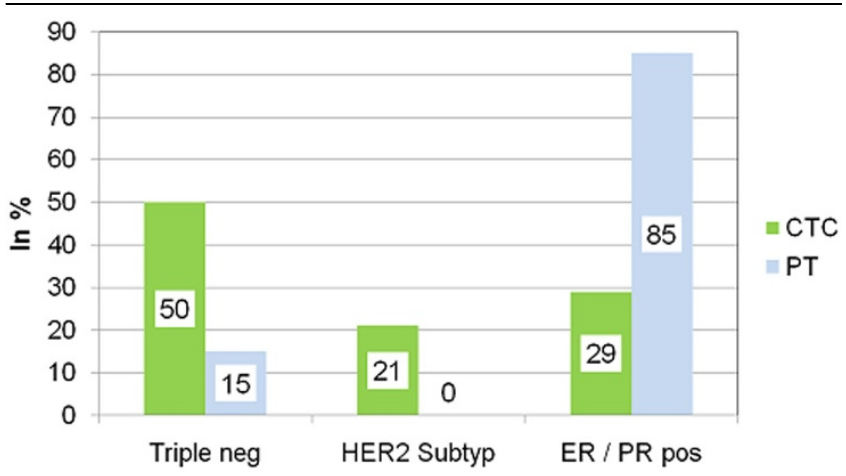

Expression of circulating tumor cells and corresponding primary tumors based on receptor status. Expression profile of circulating tumor cells (CTCs) and corresponding primary tumors (PTs) in breast cancer patients after stratifying into three different groups based on estrogen receptor (ER), progesterone receptor (PR) and human epidermal growth factor receptor 2(HER2) status: ER-positive and/or PR-positive, triple-negative (ER-negative/PR-negative/HER2-negative), and HER2positive (but ER-negative/PR-negative).

\section{Discussion}

Recent publications have indicated that the presence of CTCs and DTCs in peripheral blood and BM, respectively, does not provide congruent results and that there is a more complex relationship between the primary tumor and DTCs on the phenotype level as well on the genomic level. We demonstrate here, in a large patient group: a weak correlation between the presence of CTCs in peripheral blood and the presence of DTCs in BM; that CTCs are more closely related to the biology of the primary tumor than DTCs; that the majority of CTCs are triple-negative, regardless of the antigen expression of the primary tumor; and, most interestingly, that CTCs mostly derive from triple-negative tumors.

\section{Incidence of circulating tumor cells in primary breast cancer}

Using a multiplex RT-PCR approach, our positivity rate was $13 \%$ in primary breast cancer. Detection rates reported by other researchers using different approaches range from $9 \%$ to $50 \%$ depending on the clinical stages included [11-21,2730]. There is still currently an ongoing debate whether the (RT)PCR-based approach (for example, the AdnaTestBreastCan$\mathrm{cer}^{\mathrm{TM}}$ ) or the antibody-based approach (for example, the CellSearch $^{\mathrm{TM}}$ system) is superior in a clinical setting to monitor therapy response and to predict prognosis.

False positive results can be obtained using both the molecular approach and the antibody-based assay since only epithelial but not unique breast cancer specific markers are available for identification of breast cancer tumor cells. These markers can also be expressed in contaminating stimulated leukocytes $[19,39]$. The antibody-based approach allows a morphological assessment to confirm malignancy based on cytomorphological criteria [33,34]. In contrast, the RT-PCR approach seems to be more sensitive and allows easy multiple marker testing $[39,40]$.

Until now, only few studies have compared both techniques $[40,41]$. Trials have been initiated (for example, the DETECT Study) to determine the CTC status using both the antibodybased assay and the molecular-based approach to elucidate which assay provides more valid data in predicting therapy response and prognosis [26].

Correlation between circulating tumor cells in peripheral blood and disseminated tumor cells in bone marrow

Some research groups compared the relationship between the presence of DTCs in BM and CTCs in blood [15-18]. In general, correlation between DTCs and CTCs is low. It has been demonstrated that, in contrast to the detection of DTCs in BM of patients with early disease, detection of CTCs appears to be less sensitive and less prognostic [16,17]. Furthermore, there is growing evidence that the prognosis of women with primary breast cancer depends on DTCs rather than CTCs $[15,16,42]$. In our study, there was a weak correlation between the presence of CTCs in peripheral blood and the presence of DTCs in BM, and the presence of CTCs was more closely related to the biology of the primary tumor than DTCs. Only the clinical follow-up data of the patients, however, will elucidate the prognostic significance of either CTCs or DTCs, or both.

\section{Expression profile of circulating tumor cells compared with the primary tumor}

The aim of adjuvant treatment is to eliminate minimal residual disease reflected by CTCs and DTCs. The predictive markers ER, PR and HER2, however, are determined in the primary tumor to determine whether HER2 targeted therapy and endocrine therapy will be effective. One of the main objectives of the present paper was therefore to determine the concordance of the predictive markers ER, PR and HER2 between CTCs and corresponding primary tumors.

On the phenotype level, the expression of HER2 on DTCs or CTCs of patients with primary breast cancer has been published by different groups - who independently indicated that HER2 expression on both DTCs and CTCs differed from HER2 expression in the primary tumor and that the expression of HER2 on DTCs and CTCs was correlated with poor prognosis [32,43-46]. These observations might have clinical relevance when selecting patients for HER2 targeted therapy. Patients with HER2-negative tumors but HER2-positive CTCs might also benefit from HER2 targeted therapy. In a metastatic setting, Meng and colleagues have already shown that metastatic patients who were regarded as HER2-negative on the basis of HER2 expression of their primary tumor had circulating HER2-positive cells and responded to trastuzumab [47]. 
Similarly, the hormonal status of DTCs and CTCs could be completely different from that of the primary tumor, which on the one hand (tumor-negative, DTC/CTC-positive) could increase the number of patients eligible for endocrine therapy and on the other (tumor-positive, DTC/CTC-negative) could explain why endocrine therapy fails in a subset of hormone receptor-positive patients. Ditsch and colleagues, in an observational study looking at 17 primary tumors and their corresponding DTCs, found that only 2 out of 11 patients (18\%) with ER $\alpha$-positive primary tumors had ER $\alpha$-positive DTCs [48]. We recently demonstrated in a cohort of 254 patients with primary breast cancer that the primary tumor and DTCs in BM displayed a concordant ER $\alpha$ status in only $28 \%$ of cases [31].

Studies comparing the expression of HER2 as well as ER/PR expression of the primary tumor with CTCs have rarely been published. As already published in our study on metastatic breast cancer, we here show that CTCs were more likely to be ER-negative and PR-negative compared with the primary tumor. In contrast, CTCs were HER2-positive in 38\% of the patients whereas only $16 \%$ of the corresponding primary tumors expressed HER2 $[49,50]$. The results are therefore similar to the data derived from the DTC studies.

These phenotypical changes or discrepancies between the primary tumor, DTCs and CTCs are not confined to hormonal receptors and HER2 alone, since other studies looking at markers such as MHC III, Ki-76 and EGF-R have reported similar discrepancies [51-53]. In summary, all published data suggest that CTCs and DTCs may represent a unique and heterogeneous cell population.

Looking at a large patient group, our data confirm these previous findings of smaller studies, indicating that reliance on the phenotype of the primary tumor can be misleading since HER2 as well as the hormonal receptors were differently expressed on CTCs as compared with the primary tumor. These results have major implications for selecting adjuvant treatment. Since the expression profile of predictive markers of DTCs and CTCs, the target of adjuvant treatment, differs from the corresponding primary tumor, the next step is to design a clinical trial stratifying adjuvant treatment based on the expression profile of CTCs or DTCs versus the primary tumor to determine whether patients will derive more benefit from therapy selected based on the expression profile of minimal residual disease.

\section{Characterization of circulating tumor cells and corresponding shedding primary tumors}

On stratifying our patients into three different groups according to the tumor subtype classifications, the majority of patients had ER/PR-positive tumors. Only $6 \%$ of the patients were triple-negative, which is low compared with reported incidences of 15 to $30 \%$ [54]. The low incidence may be due to the fact that nearly all patients included in this study were Caucasian and had a high socioeconomic status (for example, not obese) $[54,55]$.

CTCs were mostly found in patients with triple-negative tumors. In addition, most of the CTCs were triple-negative regardless of the subtype of the primary tumor. Different hypotheses need to be discussed with regard to our findings. One possible explanation is the clonal heterogeneity of the primary tumor, allowing only a certain subpopulation to disseminate. On first view, it seems that ER-negative, PR-negative and HER2-negative cells could more probably disseminate, corresponding to the worse prognosis of predominantly ER $\alpha$-negative tumors and - inversely - to the demonstrated decreased invasiveness and metastatic potential of ER $\alpha$-expressing breast cancer cells [56,57].

One currently discussed hypothesis is the theory that some DTCs or CTCs, the presumed precursor cells of systemic metastatic disease, are in fact cancer stem cells. As recently published, this theory states that tumor growth and formation of secondary tumors can be traced to a small subpopulation of tumor cells, so-called cancer stem cells [58,59]. At least one study has confirmed a putative stem cell phenotype in DTCs [60], and another study has shown that the majority of early DTCs detected in the BM of breast cancer patients with a CD44+/CD24- phenotype correlated with a higher prevalence of bone metastases [61]. As breast cancer stem cells have been shown to be generally triple-negative, triple-negative CTCs are in concordance with the cancer stem cell theory $[62,63]$.

\section{Conclusions}

Two major conclusions can be drawn from these results. First, CTCs and DTCs have different meanings due to the low concordance. To determine the difference in predicting prognosis, clinical follow-up is needed. Second, CTCs have a different expression profile compared with the primary tumor. The impact on adjuvant treatment can only be answered in clinical trials randomizing patients according to the expression profile based on CTCs or DTCs.

\section{Competing interests}

The authors declare that they have no competing interests.

\section{Authors' contributions}

TF, BA, OH, SV and SK-B made substantial contributions to the conception and design of the study, acquisition of data, and analysis and interpretation of the data. TF, SK-B, EFS, DW and RK were involved in drafting the manuscript or revising it. All authors read and approved the final manuscript.

\section{Acknowledgements}

The authors thank Mrs Nancy Lane (UT Southwestern Medical School, Dallas, TX, USA) for editing the manuscript. 


\section{References}

1. Diel IJ, Kaufmann M, Costa SD, Holle R, von Minckwitz G, Solomayer EF, Kaul S, Bastert G: Micrometastatic breast cancer cells in bone marrow at primary surgery: prognostic value in comparison with nodal status. I Natl Cancer Inst 1996, 88:1652-1658.

2. Braun S, Pantel K, Muller P, Janni W, Hepp F, Kentenich CR, Gastroph S, Wischnik A, Dimpfl T, Kindermann G, Riethmüller G, Schlimok G: Cytokeratin-positive cells in the bone marrow and survival of patients with stage I, II, or III breast cancer. $N$ Engl J Med 2000, 342:525-533.

3. Solomayer EF, Diel IJ, Salanti G, Hahn M, Gollan C, Schütz F, Baster G: Time independence of the prognostic impact of tumor cell detection in the bone marrow of primary breast cancer patients. Clin Cancer Res 2001, 7:4102-4108.

4. Braun S, Vogl FD, Naume B, Janni W, Osborne MP, Coombes RC, Schlimok G, Diel IJ, Gerber G, Gebauer G, Pierga JY, Marth C, Oruzio D, Wiedswang G, Solomayer EF, Kundt G, Strobl B, Fehm T, Wong GY, Bliss J, Vincent-Salomon A, Pantel K: A pooled analysis of bone marrow micrometastasis in breast cancer. $\mathrm{N} \mathrm{Engl}$ $J$ Med 2005, 353:793-802.

5. Kasimir-Bauer S, Mayer S, Bojko P, Borquez D, Neumann R, Seeber S: Survival of tumor cells in stem cell preparations and bone marrow of patients with high-risk or metastatic breast cancer after receiving dose-intensive or high-dose chemotherapy. Clin Cancer Res 2001, 7:1582-1588.

6. Braun S, Kentenich C, Janni W, Hepp F, de Waal J, Willgeroth F, Sommer $\mathrm{H}$, Pantel K: Lack of effect of adjuvant chemotherapy on the elimination of single dormant tumor cells in bone marrow of high-risk breast cancer patients. J Clin Oncol 2000, 18:80-86.

7. Wiedswang G, Borgen E, Karesen R, Qvist H, Janbu J, Kvalheim G, Nesland JM, Naume B: Isolated tumor cells in bone marrow three years after diagnosis in disease-free breast cancer patients predict unfavorable clinical outcome. Clin Cancer Res 2004, 10:5342-5348.

8. Becker S, Becker-Pergola G, Wallwiener D, Becker, Becker-Pergola G, Wallwiener D, Solomayer EF, Fehm T: Detection of cytokeratin-positive cells in the bone marrow of breast cancer patients undergoing adjuvant therapy. Breast Cancer Res Treat 2006, 97:91-96.

9. Cristofanilli M, Budd GT, Ellis MJ, Stopeck A, Matera J, Miller MC, Reuben JM, Doyle GV, Allard WJ, Terstappen LW, Hayes DF: Circulating tumor cells, disease progression, and survival in metastatic breast cancer. N Engl J Med 2004, 351:781-791.

10. Cristofanilli M, Broglio KR, Guarneri V, Jackson S, Fritsche HA, Islam R, Dawood S, Reuben JM, Kau SW, Lara JM, Krishnamurthy S, Ueno NT, Hortobagyi GN, Valero V: Circulating tumor cells in metastatic breast cancer: biologic staging beyond tumor burden. Clin Breast Cancer 2007, 7:471-479.

11. Stathopoulou A, Vlachonikolis I, Mavroudis D, Perraki M, Kouroussis Ch, Apostolaki S, Malamos N, Kakolyris S, Kotsakis A, Xenidis N, Reppa D, Georgoulias V: Molecular detection of cytokeratin19-positive cells in the peripheral blood of patients with operable breast cancer: evaluation of their prognostic significance. J Clin Oncol 2002, 20:3404-3412.

12. Gaforio JJ, Serrano MJ, Sanchez-Rovira P, Sirvent A, DelgadoRodriguez M, Campos M, de la Torre N, Algarra I, Duenas R, Lozano $A$ : Detection of breast cancer cells in the peripheral blood is positively correlated with estrogen-receptor status and predicts for poor prognosis. Int J Cancer 2003, 107:984-990.

13. Giatromanolaki A, Koukourakis MI, Kakolyris S, Mavroudis D, Kouroussis C, Mavroudi C, Perraki M, Sivridis E, Georgoulias V: Assessment of highly angiogenic and disseminated in the peripheral blood disease in breast cancer patients predicts for resistance to adjuvant chemotherapy and early relapse. Int J Cancer 2004, 108:620-627.

14. Jotsuka T, Okumura $Y$, Nakano $S$, Nitta H, Sato T, Miyachi M, Suzumura $\mathrm{K}$, Yamashita J: Persistent evidence of circulating tumor cells detected by means of RT-PCR for CEA mRNA predicts early relapse: a prospective study in node-negative breast cancer. Surgery 2004, 135:419-426.

15. Pierga J-Y, Bonneton Ch, Vincent-Salomon A, de Cremoux $P$, Nos $C$, Blin N, Pouillart P, Thiery JP, Magdelenat H: Clinical significance of immunocytochemical detection of tumor cells using digital microscopy in peripheral blood and bone marrow of breast cancer patients. Clin Cancer Res 2004, 10:1392-1400.

16. Benoy IH, Elst H, Philips M, Wuyts $H$, Van Dam P, Scharpe S, Van Marck E, Vermeulen PB, Dirix LY: Real-time RT-PCR detection of disseminated tumour cells in bone marrow has superior prognostic significance in comparison with circulating tumour cells in patients with breast cancer. Br J Cancer 2006, 94:672-680.

17. Wiedswang G, Borgen E, Schirmer C, Karesen R, Kvalheim G, Nesland JM, Naume B: Comparison of the clinical significance of occult tumor cells in blood and bone marrow in breast cancer. Int J Cancer 2006, 118:2013-2019.

18. Mueller V, Stahmann N, Riethdorf S, Rau T, Zabel T, Goetz A, Jänicke $F$, Pantel K: Circulating tumor cells in breast cancer: correlation to bone amrrow micrometastases, heterogeneous response to systemic therapy and low proliferative activity. Clin Cancer Res 2005, 11:3678-3685.

19. Ignatiadis M, Georgoulias V, Mavroudis D: Circulating tumor cells in breast cancer. Curr Opin Obstet Gynecol 2008, 20:55-60.

20. Ignatiadis M, Georgoulias V, Mavroudis D: Micrometastatic disease in breast cancer: clinical implications. Eur J Cancer 2008, 44:2726-2736.

21. Demel U, Tilz GP, Foeldes-Papp Z, Gutierrez B, Albert WH, Böcher O: Detection of tumour cells in the peripheral blood of patients with breast cancer. development of a new sensitive and specific immunomolecular assay. J Exp Clin Cancer Res 2004, 23:465-468.

22. Zieglschmid V, Hollmann C, Gutierrez B, Albert W, Strothoff D Gross E, Bocher O: Combination of immunomagnetic enrichment with multiplex RT-PCR analysis for the detection of disseminated tumor cells. Anticancer Res 2005, 25:1803-1810.

23. Lankiewicz S, Gutierrez, Rivero B, Böcher O: Quantitative realtime RT-PCR of disseminated tumor cells in combination with immunomagnetic cell enrichment. Mol Biotechnol 2006, 34:15-28.

24. Andreopoulou E, Urbauer DL, Krishnamurthy S, Reuben JM, Valero $\mathrm{V}$, Cristofanilli M, Fritsche $\mathrm{H}$ : Comparison of circulating tumor cells (CTCs) in metastatic breast cancer (MBC): AdnaTest breast cancer for detection and biological characterization AACR Meeting Abstracts 2008, 2008:A6.

25. Dirix LY, Elst $\mathrm{H}$, Benoy I, Auw I Van der, Prové A, Wuyts $\mathrm{H}$, Maes $H$, van Dam $P$, Huget $P$, Vermeulen $P$, Sint-Augustinus AZ: Circulating tumor cell detection: a direct comparison between the CellSearch system, the AdnaTest, and CK-19/mammaglobin RT-PCR in patients with metastatic breast cancer [abstract]. $J$ Clin Oncol 2009, 27(Suppl):e22117.

26. DETECT Study [http://www.detect-study.de]

27. Xenidis N, Perraki M, Kafousi M, Apostolaki S, Bolonaki I, Stathopoulou A, Kalbakis K, Androulakis N, Kouroussis C, Pallis T, Christophylakis C, Argyraki K, Lianidou E, Stathopoulos S, Georgoulias V, Mavroudis D: Predictive and prognostic value of peripheral blood cytokeratin-19 mRNA-positive cells detected by real-time polymerase chain reaction in node-negative breast cancer patients. J Clin Oncol 2006, 24:3756-3762.

28. Ignatiadis $\mathrm{M}$, Xenidis $\mathrm{N}$, Perraki M, Apostolaki S, Politaki E, Kafousi M, Stathopoulos EN, Stathopoulou A, Lianidou E, Chlouverakis G, Sotiriou C, Georgoulias V, Mavroudis D: Different prognostic value of cytokeratin-19 mRNA positive circulating tumor cells according to estrogen receptor and HER2 status in early-stage breast cancer. J Clin Oncol 2007, 25:5194-5202.

29. Xenidis N, Ignatiadis M, Apostolaki S, Perraki M, Kalbakis K, Agelaki S, Stathopoulos EN, Chlouverakis G, Lianidou E, Kakolyris S, Georgoulias V, Mavroudis D: Cytokeratin-19 mRNA-positive circulating tumor cells after adjuvant chemotherapy in patients with early breast cancer. J Clin Oncol 2009, 27:2177-2184.

30. Rack B, Schindlbeck C, Schneeweiss A, Schrader I, Lorenz R, Beckmann M, Pantel K, Lichtenegger W, Sommer H, Janni W, for the SUCCESS Study Group: Prognostic relevance of CTC in peripheral blood of breast cancer patients before and after neoadjuavnt chemotherapy: the German SUCCESS-trial [abstract]. Proc Am Soc Clin Oncol 2008, 26:35.

31. Fehm T, Krawczyk N, Solomayer EF, Becker-Pergola G, DürrStörzer S, Neubauer H, Seeger H, Staebler A, Wallwiener D, Becker S: ER $\alpha$-status of disseminated tumor cells in bone marrow of primary breast cancer patients. Breast Cancer Res 2008, 10:R76.

32. Solomayer EF, Becker S, Pergola-Becker G, Bachmann R, Kramer B, Vogel U, Neubauer H, Wallwiener D, Huober J, Fehm TN: Com- 
parison of HER2 status between primary tumor and disseminated tumor cells in primary breast cancer patients. Breast Cancer Res Treat 2006, 98:179-184.

33. Fehm T, Braun S, Müller V, Janni W, Gebauer G, Marth C, Schindlbeck $\mathrm{C}$, Wallwiener $\mathrm{D}$, Borgen $\mathrm{E}$, Naume B, Pantel K: A concept for the standardized detection of disseminated tumor cells in bone marrow of patients with primary breast cancer and its clinical implementation. Cancer 2006, 107:885-892.

34. Borgen E, Naume B, Nesland JM, Kvalheim G, Beiske K, Fodstad O, Diel I, Solomayer EF, Theocharous P, Coombes RC, Smith BM, Wunder E, Marolleau JP, Garcia J, Pantel K: Standardization of the immunocytochemical detection of cancer cells in BM and blood: I. Establishment of objective criteria for the evaluation of immunostained cells: the European ISHAGE Working Group for Standardization of Tumor Cell Detection. Cytotherapy 1999, 5:377-388.

35. Hauch S, Zimmermann S, Lankiewicz S, Zieglschmid V, Böcher O, Albert WH: The clinical significance of circulating tumour cells in breast cancer and colorectal cancer patients. Anticancer Res 2007, 27:1337-1341.

36. Ellis IO, Schnitt SJ, Sastre-Garau X, Bussolati G, Tavassoli FA: Invasive breast carcinoma. In World Health Organization Classification of Tumours. Tumours of the Breast and Female Genital Organs Edited by: Tavassoli FA, Devilee P. Lyon: IARC Press; 2003:13-59.

37. Sobin LH, Wittekind C: International Union against Cancer. In TNM Classification of Malignant Tumours 6th edition. New York: Wiley-Liss; 2002

38. Lal P, Salazar PA, Hudis CA, Ladanyi M, Chen B: HER-2 testing in breast cancer using immunohistochemical analysis and fluorescence in situ hybridization: a single-institution experience of 2,279 cases and comparison of dual-color and single-color scoring. Am J Clin Pathol 2004, 121:631-636.

39. Sieuwerts AM, Kraan J, Bolt-de Vries J, Spoel P van der, Mostert B, Martens JW, Gratama JW, Sleijfer S, Foekens JA: Molecular characterization of circulating tumor cells in large quantities of contaminating leukocytes by a multiplex real-time PCR. Breast Cancer Res Treat 2008 in press.

40. Schoenfeld A, Kruger KH, Gomm J, Sinnett HD, Gazet JC, Sacks $\mathrm{N}$, Bender HG, Luqmani $\mathrm{Y}$, Coombes RC: The detection of micrometastases in the peripheral blood and bone marrow of patients with breast cancer using immunohistochemistry and reverse transcriptase polymerase chain reaction for keratin 19. Eur J Cancer 1997, 33:854-861.

41. Becker S, Becker-Pergola G, Banys M, Krawczyk N, Wallwiener D, Solomayer E, Schuetz C, Fehm T: Evaluation of a RT-PCR based routine screening tool for the detection of disseminated epithelial cells in the bone marrow of breast cancer patients. Breast Cancer Res Treat 2009, 117:227-33.

42. Bidard FC, Vincent-Salomon A, Gomme S, Nos C, de Rycke Y, Thiery JP: Disseminated tumor cells of breast cancer patients: a strong prognostic factor for distant and local relapse. Clin Cancer Res 2008, 14:3306-3311.

43. Braun S, Schlimok G, Heumos I, Schaller G, Riethdorf L, Riethmuller G, Pantel K: ErbB2 overexpression on occult metastatic cells in bone marrow predicts poor clinical outcome of stage I-III breast cancer patients. Cancer Res 2001, 61:1890-1895.

44. Vincent-Salomon AJ, Couturier C, Nos X: HER2 gene status assessment in micrometastatic cells in bone marrow (BM) of breast cancer patients by fluorescence in situ hybridization. $J$ Clin Oncol 2004, 22:9520.

45. Becker S, Becker-Pergola G, Fehm T, Wallwiener D, Solomayer EF: HER2 expression on disseminated tumor cells from bone marrow of breast cancer patients. Anticancer Res 2005, 25:2171-2176.

46. Wulfing $\mathrm{P}$, Borchard J, Buerger $\mathrm{H}$, Heidl S, Zanker K, Kiesel L, Brandt B: HER2-positive circulating tumor cells indicate poor clinical outcome in stage I to III breast cancer patients. Clin Cancer Res 2006, 12:1715-1720.

47. Meng S, Tripathy D, Frenkel EP, Shete S, Naftalis EZ, Huth JF, Beitsch PD, Leitch M, Hoover S, Euhus D, Haley B, Morrison L, Fleming TP, Herlyn D, Terstappen LWMM, Fehm T, Tucker TF, Lane N, Wang J, Uhr JW: Circulating tumor cells in patients with breast cancer dormancy. Clin Cancer Res 2004, 10:8152-8162.

48. Ditsch N, Mayer B, Rolle M, Untch M, Schildberg FW, Funke I: Estrogen receptor expression profile of disseminated epithe- lial tumor cells in bone marrow of breast cancer patients. Recent Results Cancer Res 2003, 162:141-147.

49. Tewes M, Aktas B, Welt A, Mueller S, Hauch S, Kimmig R, KasimirBauer S: Molecular profiling and predictive value of circulating tumor cells in patients with metastatic breast cancer: an option for monitoring response to breast cancer related therapies. Breast Cancer Res Treat 2009, 115:581-90.

50. Fehm T, Becker S, Duerr-Stoerzer S, Sotlar K, Mueller V, Wallwiener D, Lane N, Solomayer E, Uhr J: Determination of HER2 status using both serum HER2 levels and circulating tumor cells in patients with recurrent breast cancer whose primary tumor was HER2 negative or of unknown HER2 status. Breast Cancer Res 2007, 9:R74.

51. Pantel K, Schlimok G, Kutter D, Schaller G, Genz T, Wiebecke B, Backmann R, Funke I, Riethmuller G: Frequent down-regulation of major histocompatibility class I antigen expression on individual micrometastatic carcinoma cells. Cancer Res 1991, $51: 4712-4715$

52. Pantel K, Schlimok G, Braun S, Kutter D, Lindemann F, Schaller G, Funke I, Izbicki JR, Riethmuller G: Differential expression of proliferation-associated molecules in individual micrometastatic carcinoma cells. J Natl Cancer Inst 1993, 85:1419-1424.

53. Italiano A, Saint-Paul MC, Caroli-Bosc FX, Francois E, Bourgeon A, Benchimol D, Gugenheim J, Michiels JF: Epidermal growth factor receptor (EGFR) status in primary colorectal tumors correlates with EGFR expression in related metastatic sites: biological and clinical implications. Ann Oncol 2005, 16:1503-1507.

54. Bauer KR, Brown M, Cress RD, Parise CA, Caggiano V: Descriptive analysis of estrogen receptor (ER)-negative, progesterone receptor (PR)-negative, and HER2-negative invasive breast cancer, the so-called triple-negative phenotype: a populationbased study from the California Cancer Registry. Cancer 2007, 109:1721-1728

55. Carey LA, Perou CM, Livasy CA, Dressler LG, Cowan D, Conway K, Karaca G, Troester MA, Tse CK, Edmiston S, Deming SL, Geradts J, Cheang MC, Nielsen TO, Moorman PG, Earp HS, Millikan RC: Race, breast cancer subtypes, and survival in the Carolina Breast Cancer Study. JAMA 2006, 295:2492-2502.

56. Thompson EW, Paik S, Brunner N, Sommers CL, Zugmaier G, Clarke R, Shima TB, Torri J, Donahue S, Lippman ME: Association of increased basement membrane invasiveness with absence of estrogen receptor and expression of vimentin in human breast cancer cell lines. J Cell Physiol 1992, 150:534-544.

57. Platet N, Prevostel C, Derocq D, Joubert D, Rochefort H, Garcia $\mathrm{M}$ : Breast cancer cell invasiveness: correlation with protein kinase $\mathbf{C}$ activity and differential regulation by phorbol ester in estrogen receptor-positive and -negative cells. Int J Cancer 1998, 75:750-756.

58. Reya T, Morrison SJ, Clarke MF, Weissman IL: Stem cells, cancer, and cancer stem cells. Nature 2001, 414:105-111.

59. Al-Haij M, Wicha MS, Benito-Hernandez A, Morrison SJ, Clarke MF: Prospective identification of tumorigenic breast cancer cells. Proc Natl Acad Sci USA 2003, 100:3547-3549.

60. Balic M, Lin H, Young L, Hawes D, Giuliano A, McNamara G, Datar $\mathrm{RH}$, Cote RJ: Most early disseminated cancer cells detected in bone marrow of breast cancer patients have a putative breast cancer stem cell phenotype. Clin Cancer Res 2006, 12:5615-5621.

61. Abraham BK, Fritz $\mathrm{P}, \mathrm{McClellan} \mathrm{M}$, Hauptvogel $\mathrm{P}$, Athelogou $\mathrm{M}$, Brauch H: Prevalence of CD44+/CD24-/low cells in breast cancer may not be associated with clinical outcome but may favor distant metastasis. Clin Cancer Res 2005, 11:1154-1159.

62. Dontu G, El-Ashry D, Wicha MS: Breast cancer, stem/progenitor cells and the estrogen receptor. Trends Endocrinol Metab 2004 15:193-197.

63. Asselin-Labat ML, Shackleton M, Stingl J, Vaillant F, Forrest NC, Eaves CJ, Visvader JE, Lindemann GJ: Steroid hormone receptor status of mouse mammary stem cells. J Nat/ Cancer Inst 2006, 98:1011-1014. 